Global Journal of Business and Social Science Review

a-

Journal homepage: www.gatrenterprise.com/GATRJournals/index.html

Global J. Bus. Soc. Sci. Review 5 (1) 46 - 52 (2017)

\title{
The Influence of the Quality of an Audit to Relationship Other Comprehensive Income (OCI) And Relevance of Value Accounting Information, And Asymmetry of Information (Study on Companies in Indonesia)
}

\author{
Yurniwati $^{1 *}$, Amsal Djunid ${ }^{2}$, Nini Sumarni ${ }^{3}$ and Ike Pranita ${ }^{4}$ \\ 1,2,3,4 Andalas University, Indonesia.
}

\begin{abstract}
Objective - This study examines the influence of the quality of an audit to the relationship of Other Comprehensive Income (OCI) and Relevance of Value Accounting Information, and Asymmetry of Information in Indonesia's companies.

Methodology/Technique - This research uses secondary data obtained from the company's annual report in 2012 - 2014. A purposive sampling method is used to collect data and the analysis of the hypothesis was conducted using multiple linear regression analysis.

Findings - The research has shown that Quality of Audit has a significant influence to the relationship of the OCI disclosure and Relevance of Value Accounting Information has a value of sig. 0.000, F calculate is 26.816 larger than F table 2.396 and adjusted $\mathrm{R}$ square 0.241 .

Novelty - The study looks at the disclosures of OCI component's role in the investors decision making and it increases value relevance of accounting information and reducing information asymmetry.

Type of Paper: Empirical.
\end{abstract}

Keywords: Other Comprehensive Income (OCI); Relevance of Value Accounting Information; Information Asymmetry; Quality of Audit.

JEL Classification: D82, M41, M42.

\section{Introduction}

The presentation of comprehensive income statements and other comprehensive income (OCI) is very important because they can improve the relevance of value accounting information and help users of financial statements in decisions making processes. The more disclosure of information in financial statements, the better advised investors are in relation to the condition of a company. The more specific the information contained in financial statements is, the higher the value of its content and relevance (Hasan \& Asoka, 2003).

* Paper Info: Revised: September, 2016

Accepted: January, 2017

* Corresponding author:

E-mail: yurniwati.fekon.unand@gmail.com

Affiliation: Andalas University, Indonesia. 
The Indonesian Institute of Accountants (IAI), since 2012, already require companies to present financial statements disclosing Other Comprehensive Income (OCI) items in income statements as well as in the notes to financial statements, in order to support business decision making (SFAS No. 1). The difference of the interests of stakeholders can bring asymmetry of information.

The asymmetry of information that occurs between the management (agent) and owner (the principal) provides an opportunity for managers to act opportunisticly, for the sake of personal gain (Ujiyantho, 2007). This information asymmetry can be reduced by means of transparency in financial reporting and conducting audits of financial statements. The ability of an auditor to understand the business processes and the accounting system in assessing the financial statements properly reflects the quality of the audit (DeAngelo, 1981). The quality of audits is often associated with the size of the accounting firm. The big four usually have a better audit quality compared to other firms (Lee \& Park, 2013). The greater the ratio of partners to other employees, the greater the capacity to serve clients; hence the quality of the experience of the firm will be higher than other accounting firms (Eshlemen \& Guo, 2014).

The relevance of value is one of basic attributes of accounting quality replay (Francis et al., 2004). The more specific the explanation of the variables in the financial statement is, the greater the value of the audit (Hasan \& Asoka, 2003). OCI has not been fully implemented in Indonesia. The results of the research on OCI on the financial sector, mining and manufacturing shows that the ratio of OCI/NI is still small (Yurniwati, 2016) and the components of OCI are likely to appear because the financial sector is related to SFAS 55. For companies, the mining and manufacturing sectors are related to gains and losses arising from the translation of foreign entities on the foreign exchange. The OCI ratio reported during the years between 2012 and 2014 was below 25\% compared to NI and CI. Meanwhile, a single statement format is selected by many companies when reporting comprehensive income.

Wider disclosure in financial statements will provide more transparent information for stakeholders and will reduce the risk of information asymmetry. The quality of audits acts to strengthen ties of OCI with the asymmetry of information because of the ability of auditors to understand the business processes and accounting system (DeAngelo, 1981). Audit Quality is thought to influence the relationship of disclosure of other comprehensive income (OCI) with information asymmetry. Audit quality is also thought to strengthen relationships of OCI with the value relevance of accounting information.

\section{Literature Review}

Agency theory explains how information asymmetry occurs in a company. Stakeholders need tools to reduces the risk of asymmetry of information through disclosure in the company's annual reports. An agency relationship is a contract that occurs between the manager (agent) and the owner of the company (the principal) (Jensen \& Meckling, 1976; Anthony \& Govindarajan, 2005). Agency problems often arise due to the opportunistic behavior of the agent. Agents know whether their decision is in the interests of the principal or not and the agent knows more than the principal condition of the company. This is personal information and an agent motivated to deliberately do wrong, this information can create a moral hazard (Anthony and Govindarajan, 2005). More disclosure will increase information transparency and will reduce the risk of information asymmetry.

The signalling theory explains that companies with substantial leverage could be used by managers as a optimistic signal of the future of the company (Ross, 1979). This theory emerged because of the problem of information asymmetry. Due to information asymmetry conditions which have existing from time to time, the company must maintain spare capacity of loans to keep lending rates low. Information published will give a signal to investors in making investment decisions. At such time as the information is made available and all market participants have received such information, market participants must first analyze and interpret this information as a good signal (good news) or a bad signal (bad news) (Jogiyanto 2010; Brigham and Houston, 2011). If the announcement of such information as a good signal for investors, then there is a change in the volume of stock trading (Shape, 2006). In the signaling theory, management sends a signal to stakeholders as 
presented in the statement of comprehensive income which also signals positive or negative, which is thought to affect the stock price.

Relevance of Value Accounting Information relates to the ability of accounting numbers to summarize the information underlying the company's stock market price (Francis \& Schipper, 1999; Cahyonowati \& Ratmono, 2012; Barth et al., 2008). Profit is thought to have value relevance because it has a statistical relationship with stock returns that reflect the value of the company (Ball and Brown (1968). Research on the relevance of value accounting information can not be separated from the stock price. The market reaction is indicated by the change in the stock price.

Information Asymmetry is where "one side of the negotiation process has better information than the other" (Pindyck \& Rubinfield 2001; Lin and Rong, 2011). Asymmetry of information is actually at the root of the problem of accounting information before of the occurrence of fraud and manipulation of accounting profits (Lin and Rong, 2011) that is an adverse selection and a moral hazard (Scott, 2006). To overcome information asymmetry, management should engage in full disclosure of the conditions in the company's financial statements, thus reducing the asymmetry obtained by the agent and the principal (Healy and Palepu, 2001). Asymmetry of information is proxied by the bid-ask spread. There are three components in determining the bid-ask spread, as proposed by Krinsky and Lee (1996): order processing cost, inventory holding cost and adverse selection cost.

The term 'Statement of Comprehensive Income' has been used since the enactment of SFAS 1. In the context of the IFRS, convergence is the adoption of IAS 1 (2007). Income statements present comprehensive income and other comprehensive income with an all inclusive approach with the additional term "comprehensive". It not only presents all owner changes in equity but also reveals details of how the profits or losses were obtained, with further disclosure provided in the notes to the financial statements. The changes appear with the revision of SFAS 1 (Revised 2009). The Company shall present and disclose other comprehensive income (OCI) in profit or loss either directly in the income statement or separately in the notes to the financial statements.

Other comprehensive income (OCI) contains items of income and expense (including reclassification adjustments) that are not recognized in the income statement as required by SFAS before the revision in 2009 . The components of OCI are presented in the statement of comprehensive income as follows; (1) changes in revaluation surplus of fixed assets and intangible assets (SFAS 16: Fixed Asset and SFAS 19 Intangible Assets), (2) cctuarial gains and losses on defined benefit plan (SFAS 24: Employee benefits), (3) gains and losses arising from the translation of foreign currencies (SFAS 10: The Effects of changes in foreign exchange rates), (4) gains and losses from the re-measurement of financial assets that are classified as "available for sale" (IAS 55: Financial instruments: recognition and measurement) and (5) the effective portion of gains and losses hedging instruments in the context of cash flow hedges (SFAS 55: Financial Instruments: Recognition and Measurement). The disclosure of OCI is expected to lower the level of information asymmetry.

DeAngelo (1981) found that the quality of audits is dependent on the possibility of an auditor finding errors or irregularities of applicable standards or criterion. DeAngelo argues that with the independent auditor, the chances of finding error or irregularities will be even greater. Opportunity to find such errors are said to be supported by the capability of the auditor and if the auditor wishes to express morbidities in the financial statements, they should be supported by the independence of auditors. Thus, the quality and independence of the auditor are two things that can not be disregarded in assessing the quality of audit (Nichols and Price, 1976)

H1: Quality of audit has positive effect to relationship of the OCI disclosure and relevance of value accounting information

Quality accounting information is supported by the quality of an audit. Primavera and Hidayat (2015) found that the quality of an audit does not affect the value relevance of the of OCI. These studies certify that the quality of an audit does not affect the value relevance of OCI. This is the motivation for researchers to conduct research on the relationship between the disclosure of $\mathrm{OCI}$ and the value relevance of accounting information 
and its relation with the quality of the audit. Dopuch (2000) believes that the accounting firms with the best reputation are more often the large accounting firms. This means that the size of the firm in terms of number of auditors also has an effect on the audit quality, probably because it is possible to perform a second review of the results because there are more resources available.

H2: Quality of audit has a positive effect to the relationship of OCI disclosure and the asymmetric of information.

Fargher and Zhang (2014), who found that the components in OCI requires measurement at fair value, believe that companies need estimates, assumptions and judgments. This requires an audit conducted by an auditor of a large accounting firm. The big four have a better ability to assess and examine the error made by the company (Lee and Park, 2013). So, with a good audit quality, disclosure of OCI is expected to reflect the actual conditions of the company and is able to reduce the level of information asymmetry.

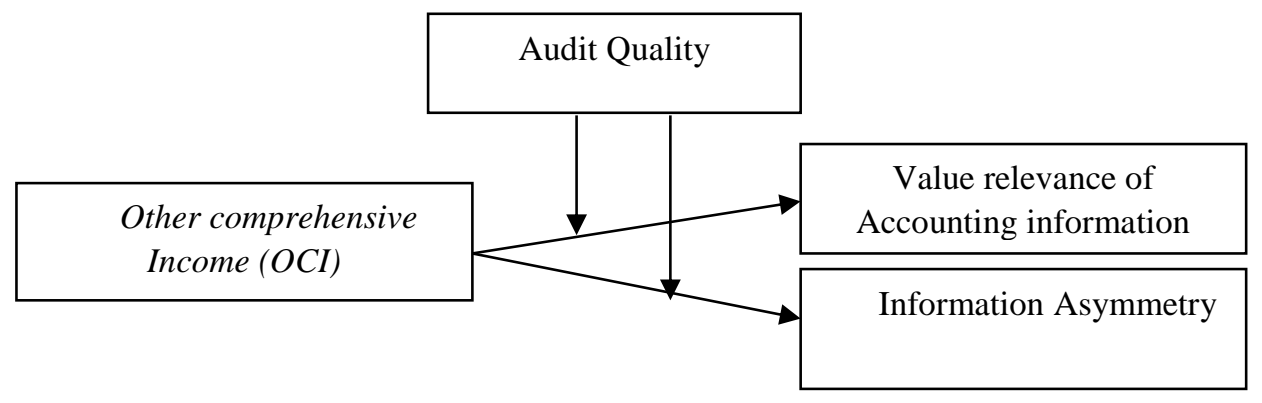

Figure No. 1: The Research Model

\section{Research methods}

This research is a descriptive verification empirical study with quantitative approach. It uses secondary data, financial data and profiles of companies listed on the Indonesia Stock Exchange between 2012 and 2014. The first dependent variable is the value relevance of accounting information which is proxied by stock prices and the individual stock price average at the time of the closing price on March $28(\mathrm{P}-3)$ and 3 April $(\mathrm{P}+3)$. This is calculated by the following formula:

$$
\text { Price }=\text { Ln stock price }(P+3)+(P-3) / 2
$$

The second dependent variable is proxied by using the Information Asymmetry bid-ask spread (SPREAD) calculated by the following formula:

$$
\text { SPREAD } i, t=(\text { ask } 1, t-\text { bid } i, t) /((\text { ask } i, t+\text { bid } i, t) 2) * 100 \%
$$

The independent variable in this study is the disclosure of other comprehensive income (OCI). It is based on research conducted by Lin and Rong (2011) using the ratio of OCI to all comprehensive income, calculated as follows:

\section{OCI ratio $=$ OCI/all comprehensive income}

The moderating variable in this study is the quality of the audit. The proxy used for this variable is the size of the accounting firm; the big four and non big four measured by dummy variables. If the company uses the big four audit companies, their services will be given a weight of 1 , whereas if companies use the services of 
non big four accounting firm, they will be given a score of 0 . The accounting firms comprising the big four are as follows: (1) Deloitte Touche Tohmatsu (Deloitte), (2) Ernst and Young (E\&Y), (3) Klynveld Geordeler Peat Marwick (KPMG) and (4) Pricewaterhouse Coopers (PwC).

The population of this research is companies listed on the Indonesian Stock Exchange during the years between 2012 and 2014. Samples were selected using a purposive sampling method with the criterion being the issuing of financial statements and Other Comprehensive Income (OCI), it must not be a loss, Rupiah must be used in financial reporting and there must be no mergers or acquisitions between in 2012 and 2014 .

\section{Results and Discussion}

There were 444 companies listed in the Indonesia Stock Exchange between 2012 and 2014. 259 companies had not reported OCI, 54 companies were using USD in their financial statements and 42 companies did not provide the required data for the study. In order to obtain as many as 89 companies in the sample, we included 267 observations.

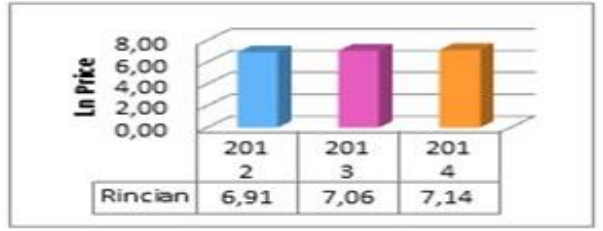

Figure 2. Value Relevance of Accounting Information

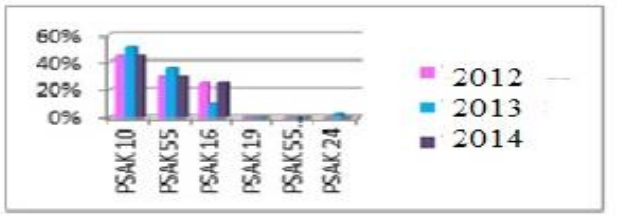

Figure 3. Audit Quality

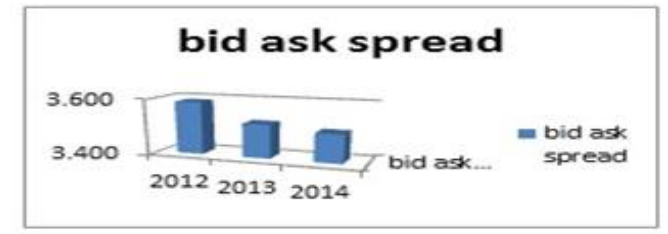

Figure 3. Information Asymmetry

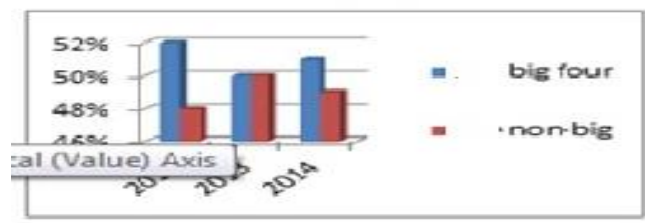

Figure 4. Other Comprehensive Income (OCI)

The results showed a relationship between the quality of audits to the relationship of disclosure of other comprehensive income (OCI) with the value relevance of accounting information. This is shown in the F test results; $\mathrm{F}$ calculate is 25.058 and $\mathrm{F}$ table is 2.406 and the significance is $0.000<0.05$, which means other comprehensive income (OCI) and audit quality simultaneously affect the value relevance of accounting information. The degree of influence of audit quality and other comprehensive income (OCI) on the value relevance of accounting information is $26.6 \%$, which is obtained from the value of adjusted R2 of 0.266 .

The results showed the joint affect of the quality of audit and disclosure of other comprehensive income to the asymmetry of information. These results are shown from the results of the $\mathrm{F}$ test statistics, with a significant value of 0.013 . Value $\mathrm{F}$ calculate is 3,226 and $\mathrm{F}$ table is 2.406 . The results are consistent with the revelation that the disclosure of other comprehensive income has a higher level of transparency and applying the principles of full disclosure is better than not disclosing other comprehensive income. The level of influence of the quality of audits to the relationship of disclosure of other comprehensive income with the asymmetry of information is only equal to $3.2 \%$, derived from the value of adjusted R2 of 0.032 .

The low effect of other comprehensive income (OCI), which is strengthened by audit quality, is suspected because there are many factors or other variables that can affect the value relevance of accounting information and asymmetry of information such as net income, book value of equity, cash flow, and others. In addition, 
disclosure and presentation of other comprehensive income (OCI) in the statement of comprehensive income is still rarely conducted by the companies listed in the Indonesia Stock Exchange. It can also reduce the level of influence of other comprehensive income (OCI) to the value relevance of accounting information, and the information asymmetry, because investors can not obtain information about OCI of all companies listed on the Indonesia Stock Exchange. The effect of the quality of an audit also amplified the effect of disclosure of other comprehensive income (OCI) with the value relevance of accounting information and information asymmetry.

\section{Conclusions}

It is concluded that audit quality significantly effects the relationship of disclosure of other comprehensive income (OCI) with the value relevance of accounting information. Further, the quality of an audit significantly affects the the relationship of disclosure of other comprehensive income with the asymmetry of information.

Other Comprehensive Income (OCI) has been shown to have value relevance of accounting information for users of financial statements however the value of OCI disclosed by companies sampled in this study does not provide a major contribution. These results are in line with the research by Yurniwati (2016) which found that the ratio of company's reported OCI for the period between 2012 and 2014 was below 25\%. Therefore, the relevant parties in the capital market need to encourage capital market participants to optimize the information contained in the financial statements, including the components of other comprehensive income. The disclosures of OCI components in financial statements has a role in the decisions of investors as other comprehensive income increases the value relevance of accounting information and reduces information asymmetry.

Limitations of the study, among others, are; (1) the study period lasted for only three years, namely, from 2012 to 2014 where in 2012 there were still many companies that did not disclose other comprehensive income (OCI), (2) the dependent variable in this study was limited to the value relevance of accounting information and information asymmetry.

Suggestions for further research are: (1) to extend the observation period to more than three years and (2) to use more independent variables in order to get better results that give a picture of other variables which can be influenced by the disclosure of other comprehensive income (OCI).

\section{References}

Anthony, Robert, N.,Vijay Govindarajan. 2005. Management Control System, edisi kesebelas. Jakarta:Salemba Empat.

Beaver, W. H., Kennelly, J. W., \& Voss, W. M. (1968). Predictive ability as a criterion for the evaluation of accounting data. The Accounting Review, 43(4), 675-683.

Belkaoui, A. R. (2000). Impact of earning manajement on value relevance of accounting information: Empirical Evidence from Japan. Departement of Accounting and Information Systems. Faculty of Business University of Dhaka, Bangladesh.

Boyton, W. C. \& Johnson, R. N. (2006). Modern Auditing. (8th Ed.). New York: John Willey \& Sons Inc.

Brigham, E. F. \& Houston, J. F. (2011). Dasar-dasar Manajemen Keuangan. (11th Ed.) Jakarta: Salemba Empat.

Cahyonowati, N. \& Ratmono, D. (2012). Adopsi IFRS dan Relevansi Nilai Informasi Akuntansi. Jurnal Akuntansi dan Keuangan, 14(2), 105-115.

Chang, Y., \& H. Liou. (2013). The Effect of IFRS and the Institutional Environment on Accounting Quality in Chinese Listed Firm. The Journal of American Business Review, 1(2).

DeAngelo, L. E. (1981). Auditor Size and Audit Quality. Journal of Accounting and Economics, 3, 183-199

Dopuch, N. \& Simunic, D. (1980). The Nature of Competition in the Auditing Profession: A Descriptive and Normative View. Regulation and the Accounting Profession, 34(2): edited by J. Buckley and F. Weston, 238-289. Belmount, CA: Lifetine Learning Publication.

Eshleman, J. D., \& Guo, P. (2014). Do Big 4 auditors provide higher audit quality after controlling for the endogenous choice of auditor? Auditing: A Journal of Practice \& Theory, 33(4), 197-219.

Fargher, N., \& Zhang, J. Z. (2014, September). Changes in the measurement of fair value: Implications for accounting earnings. In Accounting forum 38(3), 184-199). Elsevier. 
Francis, J., \& Schipper, K. (1999). Have financial statements lost their relevance? Journal of accounting Research, 37(2), 319-352.

Francis, J., LaFond, R., Olsson, P. M., \& Schipper, K. (2004). Costs of equity and earnings attributes. The accounting review, 79(4), 967-1010.

Hasan, I. \& Asoka, A. (2003). Transparency and Value Relevance: The Experience of some MENA Countries. Preliminary Version.

Healy, P. M., \& Palepu, K. G. (2001). Information asymmetry, corporate disclosure, and the capital markets: A review of the empirical disclosure literature. Journal of accounting and economics, 31(1), 405-440.

Hellström, K. (2006). The value relevance of financial accounting information in a transition economy: The case of the Czech Republic. European accounting review, 15(3), 325-349.

Ikatan Akuntan Indonesia. (2011). Standar Akuntansi Keuangan. Jakarta: Salemba Empat.

Jensen, M. C., \& Meckling, W. H. (1976). Theory of the firm: Managerial behavior, agency costs and ownership structure. Journal of financial economics, 3(4), 305-360.

Jogiyanto, H. M. (2011). Metode Penelitian Bisnis. Edisi Keempat. Yogyakarta: BPFE.

Jogiyanto. H. M. (2010). Teori Portofolio dan Analisis Investasi. Edisi Ketiga. Yogyakarta: BPFE.

Kartikahadi, H., Sinaga, R. U., Syamsul, M., \& Siregar, S. V. (2012). Akuntansi Keuangan berdasarkan SAK berbasis IFRS. Jakarta, Salemba Empat.

Krinsky, I., \& Lee, J. (1996). Earnings announcements and the components of the bid- ask spread. The Journal of Finance, 51(4), 1523-1535.

Lee, C. \& Park, M. S. (2013). Subjectivity in Fair Value Estimate, Audit Quality and in Formativeness of Other Comprehensive Income. Advance in Accounting, Incorporating Advance in International Accounting 29: 218-231

Pindyck, R. S. \& Rubinfield, D. L. (2001). Microeconomics. Ch 17 markets with Asymmetric Information, 5th. Prentice Hall.

Primavera, L. \& Hidayat, T. (2015). The Effect of Audit Quality on the Value Relevance of Other Comprehensive Income. Journal of Economics, Business, and Accountancy Ventura, 18(1), 145-154

Ross, S. A. (1977). The Determination of Financial Structure: The Incentive Signalling Approach. Journal of Economics, Spring, 8, 23-40

Scott, W. R. (2006). Financial Accounting Theory. (7th Ed.). USA: Prentice-Hall

Watts, Ross L. Dan Jerold L. Zimmerman. 1986. Possitive Accounting Theory. The Accounting Review: Jan 1990.65,1: ABI/INFORM Global. 131

Ujiyantho, M. A. (2007). Asimetri informasi dan manajemen laba: Suatu tinjauan dalam hubungan keagenan. Jurnal Riset Akuntansi Indonesia, 25-37.

Yurniwati (2016). Analisis Komponen Other Comprehensive Income (Studi pada perusahaan Perbankan, Pertambangan dan Manufaktur). Belum dipublikasikan. Padang: Universitas Andalas. 